\title{
The Influences of Human Capital (Knowledge, Skills, and Competency) on Organizational Performance: A PLS-SEM Technique
}

\author{
Mohamad Alhamad, Mohammed Nusari, Ali Ameen, Valliappan Raju, Amiya Bhumic
}

\begin{abstract}
The current research uses structural equations modeling (SEM) via PLS software in order to evaluate the 533 valid questionnaires. This is done for assessing the proposed model based on human capital variables for determining its impact on organizational performance in the UAE's public sector. The main independent constructs are knowledge, skills and competency. The dependent construct covers organizational performance. The research shall define the relationship between the various constructs. This work has improved our insight into the importance of human capital. The study results have shown prediction of organizational performance by independent variables stating a $32.8 \%$ of variance. The results have the potential to give further insights into enhancing public organizations' performance.
\end{abstract}

Keywords: Human capital; knowledge; skills; competency; organizational performance; $U A E$

\section{INTRODUCTION}

$\mathrm{S}$ As organizations in general are increasingly exposed to the global arena, they have been not only faced with the challenge of dealing with cultural differences whilst maintaining performance levels [1] but they also have had to deal with collaborative development within and between the organizations [2]. There are some of the vital areas the managers needs to focus on like physical team, virtually managed project teams, defined project goals, transparency in the project, adequate controlling methods and predefined ones, communication efficiencies and human capital assets in order to strive to overcome towards organizational success [3]. Regardless the nature and goal of organizations, the management of future organization involves network organizational structures and virtual development teams.

Due to the current environments that is known to be very competitive and innovative, the link between organizational performance (OP) and transformational leadership is never clearer, where competitive advantage is only obtained through innovativeness that enable organizations to improve

Revised Manuscript Received on September 25, 2019

Mohamad Alhamad, Faculty of Business and Accountancy, Lincoln University College, Selangor, Malaysia

Mohammed Nusari, Faculty of Business and Accountancy, Lincoln University College, Selangor, Malaysia

Ali Ameen, Faculty of Business and Accountancy, Lincoln University College, Selangor, Malaysia

Valliappan Raju, Faculty of Business and Accountancy, Lincoln University College, Selangor, Malaysia

Amiya Bhumic, Faculty of Business and Accountancy, Lincoln University College, Selangor, Malaysia their outcomes $[4,5]$. In a situation like this, managers must focus in motivating their employees to be part of the innovation processes, and continuously gain new ideas that would enable the organizations in introducing innovative market specific products [6]. Transformational leadership and human resource practices are seen as triggers of competence and innovation by recent literature study [7]. Further, Heffernan, Harney, Cafferkey, \& Dundon (2016) [8] stated a need for further work relating to variables that mediate between the two triggers mentioned above.

The current research objective states the effect of human capital in terms of knowledge, skills, and competency on public organization performance in the UAE.

\section{Literature ReVIEW}

\section{A. Organizational Performance}

One of the major variables for management is OP [9]. It evaluates the standard or prescribed indicators relating to the environmental responsibility that includes regulatory compliance, cycle time, reduction of waste and productivity, in addition to efficiency and effectiveness. Organizational performance is the researchers' eventual dependent variable who is engaged in managerial studies. This wide variable is considered important in enabling the organization's managers as well as the researchers for assessing the overtime and matching them to their rival organizations [10]. This can be proved with persistent implementation of OP as a dependent variable (Richard et al., 2009).

\section{B. Human Capital (HC)}

$\mathrm{HC}$ is defined by many social scientists and economists refers to the individuals' knowledge, skills and competency of the workforce, representing the critical resources to the organizations [11-14]. Human capital shows a vital role in helping an organization to achieve its aims in an uncertain environment [15]. It acts as a lever to attain competitive advantage. Also, is a suitable resource from which to create innovation [16]. Wang \& Chang (2005) [17] reveal that the accumulation of Human capital ought to maximize the firm's outcomes. For example, successful innovation, which is a central source of an organization's profits, depends mainly on unique assets such as Human capital [18].

Drucker (1977) [19] and Toffler (1990) [20] decide on to link knowledge to information, and used the terms interchangeably. On the other 
hand, Nonaka \& Takeuchi (1995) [21] argued that knowledge has two components namely, explicit knowledge and tacit knowledge. In the latter sense, knowledge can appear to edge into the areas of skills and attitudes. Generally, employees will accumulate knowledge through formal and informal leanings, trainings and experiences. Winter (1987) [22], suggested that tacit knowledge is the most important knowledge asset that the organizations can have, which consider as difficult to create or share. Nonaka, von Krogh, \& Voelpel (2006) [23] argued that tacit knowledge can be shared through the individuals' groups and communities, which in return can connect and their knowledge Moreover, with the new global economic, there have been a need to employ a ready skilled individuals, this in return will benefit the organizations with minimum cost [24]. In addition, skillful human capital is a key source for almost all the organizations to deliver high quality services [25]. Moreover, to improve the quality of the organizations performance, managers and leaders should retain the qualified and skillful individuals in their organizations [24].

Due to the deterioration of public resources to fulfil the increasing demand for public services, enhancing performance in the public sector is especially needed today. Public organizations' leaders have a vital role to play to improve performance and the competencies of their employees which is very crucial for their success. The competency notion to enhancing performance focuses on inputs such as the knowledge, skills, and capabilities for achievement that the employee brings to the organization, beside other personal qualities wanted to be successful. Competency based methods to management allows employees to strive for their career development. Traditional approaches contrast with the competency approach in that they are more concerned with outputs and how [26]. Consequently, the following hypothesis is proposed:

H1. Knowledgesignificantly has a positive impact onorganizational performance.

H2. Skills significantly has a positive impact onorganizational performance.

H3. Competency significantly has a positive impact onorganizational performance.

Figure 1 shows the proposed study model which contain three independent variables (knowledge, skills, and competency) and one dependent variable (organizational performance).

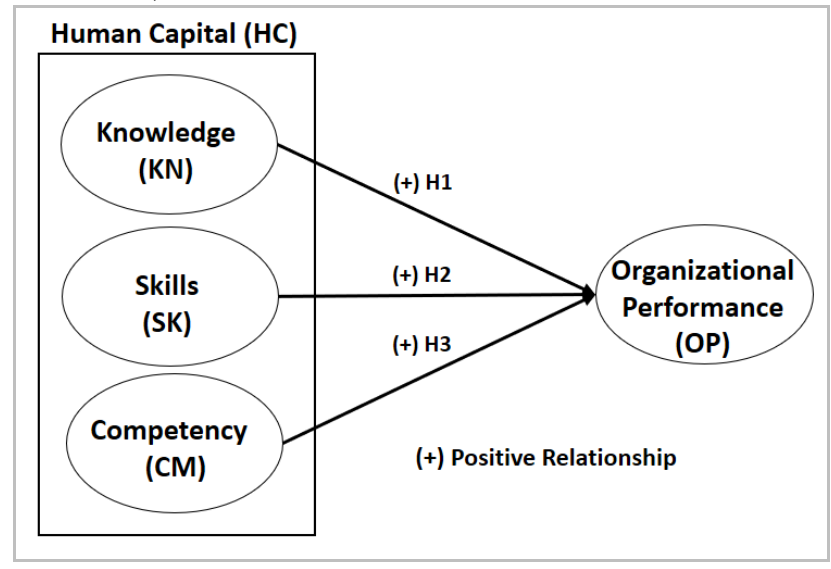

Fig 1: The proposed model

\section{RESEARCH DESIGN AND METHODOLOGY}

\section{A. Development of Instrument and Data collection}

The creation of a tool for this research involved a questionnaire of 34 questions, and on the basis of the literature on human resource management, the research employed a multi-item Likert scale [27]. The parameters were evaluated using a Likert scale recommended in the earlier studies [28]. The information was gathered by delivering a self-managed questionnaire 'in-person' between November 2018 and December 2018 to public organizations in Abu Dhabi in UAE. The number of the distributed questionnaires was 650, which 533 responses were considered suitable for the analysis. According to Tabachnick \& Fidell (2012) [29] and Krejcie \& Morgan (1970) [30], the sample size was seen as sufficient.

\section{DATA ANALYSIS AND RESUlts}

Partial Least Squares (PLS) was utilized to test the research model, using the SmartPLS 3.0 software. A two-stage analytical method [31] was used which comprising (i) measurement model assessment (validity and reliability) and (ii) structural model assessment (testing the hypothesized relationships).

\section{A.Descriptive analysis}

Competency scores the highest with mean 4.31 out of 5.0, with a standard deviation of 0.95. Organizational performance scores the lowest with mean 3.51 out of 5.0, with a standard deviation of 1.237 , as Table 1 shows.

\section{B. Measurement Model Assessment}

Construct reliability as well as validity (comprising discriminant and convergent validity) were used to examine the measurement model. The particular alpha coefficients of Cronbach were tested to determine the reliability of every core parameter in the measurement model (construct reliability). The quantities of all the unique alpha coefficients of Cronbach in this research ranged from 0.924 to 0.947 , which went beyond the proposed value of 0.7 [32]. Moreover, for inspecting construct reliability, all the CR (composite reality) values went beyond 0.7 except KN3, SK8, and OP11 $[33,34]$. Thus, as Table 1 shows, construct reliability have been fulfilled as Cronbach's CR and alpha were rather error-free for all the parameters.

Table 1: Measurement assessment results 
International Journal of Recent Technology and Engineering (IJRTE) ISSN: 2277-3878, Volume-8 Issue-2S10, September 2019

\begin{tabular}{|c|c|c|c|c|c|c|c|}
\hline Constructs & Item & $\begin{array}{l}\text { Loading } \\
(>0.5)\end{array}$ & M & SD & $\begin{array}{c}\alpha \\
(>0.7)\end{array}$ & $\begin{array}{c}\text { CR } \\
(>0.7)\end{array}$ & $\begin{array}{c}\text { AVE } \\
(>0.5) \\
\end{array}$ \\
\hline \multirow{10}{*}{$\begin{array}{c}\text { Knowledge } \\
(\mathrm{KN})\end{array}$} & KN1 & 0.866 & \multirow{10}{*}{3.95} & \multirow{10}{*}{1.036} & \multirow{10}{*}{0.960} & \multirow{10}{*}{0.966} & \multirow{10}{*}{0.760} \\
\hline & $\mathrm{KN} 2$ & 0.822 & & & & & \\
\hline & KN3 & Deleted & & & & & \\
\hline & KN4 & 0.890 & & & & & \\
\hline & KN5 & 0.885 & & & & & \\
\hline & KN6 & 0.901 & & & & & \\
\hline & KN7 & 0.871 & & & & & \\
\hline & KN8 & 0.886 & & & & & \\
\hline & KN9 & 0.855 & & & & & \\
\hline & KN10 & 0.865 & & & & & \\
\hline \multirow{10}{*}{$\begin{array}{r}\text { Skills } \\
(\mathrm{SK})\end{array}$} & SK1 & 0.833 & \multirow{10}{*}{4.09} & \multirow{10}{*}{1.027} & \multirow{10}{*}{0.957} & \multirow{10}{*}{0.963} & \multirow{10}{*}{0.745} \\
\hline & SK2 & 0.893 & & & & & \\
\hline & SK3 & 0.856 & & & & & \\
\hline & SK4 & 0.887 & & & & & \\
\hline & SK5 & 0.883 & & & & & \\
\hline & SK6 & 0.823 & & & & & \\
\hline & SK7 & 0.877 & & & & & \\
\hline & SK8 & Deleted & & & & & \\
\hline & SK9 & 0.849 & & & & & \\
\hline & SK10 & 0.863 & & & & & \\
\hline \multirow{3}{*}{$\begin{array}{l}\text { Competency } \\
\text { (CM) }\end{array}$} & CM1 & 0.906 & \multirow{3}{*}{4.31} & \multirow{3}{*}{0.95} & \multirow{3}{*}{0.934} & \multirow{3}{*}{0.958} & \multirow{3}{*}{0.883} \\
\hline & CM2 & 0.962 & & & & & \\
\hline & CM3 & 0.951 & & & & & \\
\hline \multirow{11}{*}{$\begin{array}{l}\text { Organizational } \\
\text { Performance } \\
\text { (OP) }\end{array}$} & OP1 & 0.847 & \multirow{11}{*}{3.51} & \multirow{11}{*}{1.237} & \multirow{11}{*}{0.955} & \multirow{11}{*}{0.961} & \multirow{11}{*}{0.712} \\
\hline & OP2 & 0.831 & & & & & \\
\hline & OP3 & 0.833 & & & & & \\
\hline & OP4 & 0.866 & & & & & \\
\hline & OP5 & 0.871 & & & & & \\
\hline & OP6 & 0.876 & & & & & \\
\hline & OP7 & 0.877 & & & & & \\
\hline & OP8 & 0.866 & & & & & \\
\hline & OP9 & 0.790 & & & & & \\
\hline & OP10 & 0.776 & & & & & \\
\hline & OP11 & Deleted & & & & & \\
\hline
\end{tabular}

Note: $\mathrm{M}=$ Mean;CR $=$ Composite Reliability; $\alpha=$ Cronbach's alpha; AVE = Average Variance Extracted; SD=Standard Deviation.

Key: KN: Knowledge, SK: Skills, CM: Competency, OP: Organizational Performance

The degree to which the articles distinguish among concepts or measure different constructs is demonstrated by discriminant validity. Cross-loadings as well as Fornell-Larcker were employed to analyse the measurement model's discriminant validity. Generally, cross-loadings are employed as the initial step in examining discriminant validity of the indicators. In this research, the indicators outer loadings on a construct went beyond all the cross-loadings with other parameters, and thus the cross-loading condition had met the requirements (refer to Table 2).

Table 2: Results of discriminant validity by thecross loading

\begin{tabular}{cccccccccc}
\hline TABLE I. & & TABLE II. & KN & TABLE III. & SK & TABLE IV. & CM & TABLE V. & OP \\
TABLE VI. & KN1 & TABLE VII. & $\mathbf{0 . 8 6 6}$ & TABLE VIII. & 0.550 & TABLE IX. & 0.459 & TABLE X. & 0.432 \\
TABLE XI. & KN2 & TABLE XII. & $\mathbf{0 . 8 2 2}$ & TABLE XIII. & 0.585 & TABLE XIV. & 0.477 & TABLE XV. & 0.427 \\
TABLE XVI. & KN4 & TABLE XVII. & $\mathbf{0 . 8 9 0}$ & TABLE XVIII. & 0.533 & TABLE XIX. & 0.449 & TABLE XX. & 0.386 \\
TABLE XXI. & KN5 & TABLE XXII. & $\mathbf{0 . 8 8 5}$ & TABLE XXIII. & 0.531 & TABLE XXIV. 0.453 & TABLE XXV. & 0.469 \\
TABLE XXVI. & KN6 & TABLE XXVII. $\mathbf{0 . 9 0 1}$ & TABLE XXVIII. & 0.544 & TABLE XXIX. 0.444 & TABLE XXX. 0.422 \\
TABLE XXXI. & KN7 & TABLE XXXII. $\mathbf{0 . 8 7 1}$ & TABLE XXXIII. & 0.498 & TABLE XXXIV. 0.419 & TABLE XXXV. 0.394 \\
\hline
\end{tabular}


The influences of human capital (knowledge, skills, and competency) on organizational performance: A PLS-SEM Technique

\begin{tabular}{|c|c|c|c|c|c|}
\hline TABLE XXXVI. KN8 & TABLE XXXVII. $\mathbf{0 . 8 8 6}$ & TABLE XXXVIII. & TABLE XXXIX. 0.490 & TABLE XL. & 0.485 \\
\hline TABLE XLI. & TABLE XLII. & TABLE XLIII. 0.537 & TABLE XLIV. 0.436 & TABLE XLV. & 0.392 \\
\hline TABLE XLVI. KN10 & TABLE XLVII. $\mathbf{0 . 8 6 5}$ & TABLE XLVIII. & TABLE XLIX. 0.511 & TABLE L. & 0.454 \\
\hline TABLE LI. & TABLE LII. & TABLE LIII. & TABLE LIV. & TABLE LV. & 0.339 \\
\hline TABLE LVI. SK2 & TABLE LVII. & TABLE LVIII. $\mathbf{0 . 8 5 6}$ & TABLE LIX. & TABLE LX. & 0.364 \\
\hline TABLE LXI. SK3 & TABLE LXII. & TABLE LXIII. $\mathbf{0 . 8 8 7}$ & TABLE LXIV. 0.559 & TABLE LXV. & 0.409 \\
\hline TABLE LXVI. SK4 & TABLE LXVII. 0.593 & TABLE LXVIII. $\mathbf{0 . 8 8 3}$ & TABLE LXIX. 0.519 & TABLE LXX. & 0.391 \\
\hline TABLE LXXI. SK5 & TABLE LXXII. 0.515 & TABLE LXXIII. $\mathbf{0 . 8 2 3}$ & TABLE LXXIV. 0.461 & TABLE LXXV. & 0.345 \\
\hline TABLE LXXVI. SK6 & TABLE LXXVII. 0.487 & TABLE LXXVIII. & TABLE LXXIX. $\quad 0.591$ & TABLE LXXX. & 0.453 \\
\hline TABLE LXXXI. SK7 & TABLE LXXXII. 0.468 & TABLE LXXXIII. & TABLE LXXXIV. & TABLE LXXXV & . 0.465 \\
\hline TABLE LXXXVI. SK9 & TABLE LXXXVII. 0.555 & TABLE LXXXVIII. $\mathbf{0 . 8 6 3}$ & TABLE LXXXIX. & TABLE XC. & 0.431 \\
\hline TABLE XCI. SK10 & TABLE XCII. 0.552 & TABLE XCIII. $\mathbf{0 . 8 9 3}$ & TABLE XCIV. 0.595 & TABLE XCV. & 0.474 \\
\hline TABLE XCVI. CM1 & TABLE XCVII. 0.473 & TABLE XCVIII. 0.563 & TABLE XCIX. $\mathbf{0 . 9 0 6}$ & TABLE C. & 0.420 \\
\hline TABLE CI. CM2 & TABLE CII. & TABLE CIII. $\quad 0.620$ & TABLE CIV. $\quad \mathbf{0 . 9 6 2}$ & TABLE CV. & 0.485 \\
\hline TABLE CVI. CM3 & TABLE CVII. & TABLE CVIII. 0.613 & TABLE CIX. $\quad \mathbf{0 . 9 5 1}$ & TABLE CX. & 0.475 \\
\hline TABLE CXI. OP1 & TABLE CXII. 0.384 & TABLE CXIII. 0.372 & TABLE CXIV. 0.404 & TABLE CXV. & 0.847 \\
\hline TABLE CXVI. OP2 & TABLE CXVII. 0.389 & TABLE CXVIII. 0.378 & TABLE CXIX. 0.394 & TABLE CXX. & 0.831 \\
\hline TABLE CXXI. OP3 & TABLE CXXII. 0.404 & TABLE CXXIII. 0.379 & TABLE CXXIV. 0.406 & TABLE CXXV. & 0.833 \\
\hline TABLE CXXVI. OP4 & TABLE CXXVII. 0.372 & TABLE CXXVIII. $\quad 0.385$ & TABLE CXXIX. 0.420 & TABLE CXXX. & 0.866 \\
\hline TABLE CXXXI. OP5 & TABLE CXXXII. 0.383 & TABLE CXXXIII. & TABLE CXXXIV. & TABLE CXXXV & 0.871 \\
\hline TABLE CXXXVI. OP6 & TABLE CXXXVII. 0.426 & TABLE CXXXVIII. 0.462 & TABLE CXXXIX. $\quad 0.467$ & TABLE CXL. & 0.876 \\
\hline TABLE CXLI. OP7 & TABLE CXLII. 0.445 & TABLE CXLIII. $\quad 0.425$ & TABLE CXLIV. 0.421 & TABLE CXLV. & 0.877 \\
\hline TABLE CXLVI. OP8 & TABLE CXLVII. 0.493 & TABLE CXLVIII. 0.453 & TABLE CXLIX. $\quad 0.435$ & TABLE CL. & 0.866 \\
\hline TABLE CLI. OP9 & TABLE CLII. & TABLE CLIII. $\quad 0.407$ & TABLE CLIV. 0.376 & TABLE CLV. & 0.790 \\
\hline TABLE CLVI. OP10 & TABLE CLVII. 0.387 & TABLE CLVIII. $\quad 0.346$ & TABLE CLIX. 0.372 & TABLE CLX. & 0.776 \\
\hline
\end{tabular}

Key: KN: Knowledge, SK: Skills, CM: Competency, OP: Organizational Performance.

Table 3 shows the outcomes for discriminant validity by markers in comparison to the other concepts in the model employing the Fornell-Larcker condition. It was discovered $\quad[35,36]$. According to Hair et al. (2017) [37], this indicates that the AVEs' square root on the diagonals (displayed in good discriminant validity. Furthermore, the exogenous bold) is bigger than the correlations among constructs constructs have a correlation of less than 0.85 . Therefore, all (corresponding row as well as column values), suggesting a constructs had their discriminant validity fulfilled strong association between the concepts and their respective satisfactorily.

Table 3: Results of discriminant validity by Fornell-Larcker criterion

\begin{tabular}{|c|c|c|c|c|c|c|c|}
\hline TABLE CLXI & & TABLE CLXII. & $\mathrm{CM}$ & TABLE CLXIII. KN & TABLE CLXIV. & $\mathrm{OP}$ & TABLE CLXV. SK \\
\hline TABLE CLXVI. & $\mathrm{CM}$ & TABLE CLXVII. & 0.940 & TABLE CLXVIII. & TABLE CLXIX. & & TABLE CLXX. \\
\hline TABLE CLXXI. & $\mathrm{KN}$ & TABLE CLXXII. & 0.529 & TABLE CLXXIII. $\mathbf{0 . 8 7 2}$ & TABLE CLXXIV & & TABLE CLXXV. \\
\hline TABLE CLXXVI. & $\mathrm{OP}$ & TABLE CLXXVII. & 0.491 & TABLE CLXXVIII. 0.495 & TABLE CLXXIX. & 0.844 & TABLE CLXXX. \\
\hline TABLE CLXXXI. & SK & TABLE CLXXXII. & 0.638 & TABLE CLXXXIII. 0.628 & TABLE CLXXXIV. & 0.479 & TABLE CLXXXV. \\
\hline
\end{tabular}

Key: KN: Knowledge, SK: Skills, CM: Competency, OP: Organizational Performance

Performance.

\section{C.Structural Model Assessment}

The structural model can be tested by computing beta $(\beta), \mathrm{R}^{2}$, and the corresponding $\mathrm{t}$-values via a bootstrapping procedure with a resample of 5,000 [37]. 


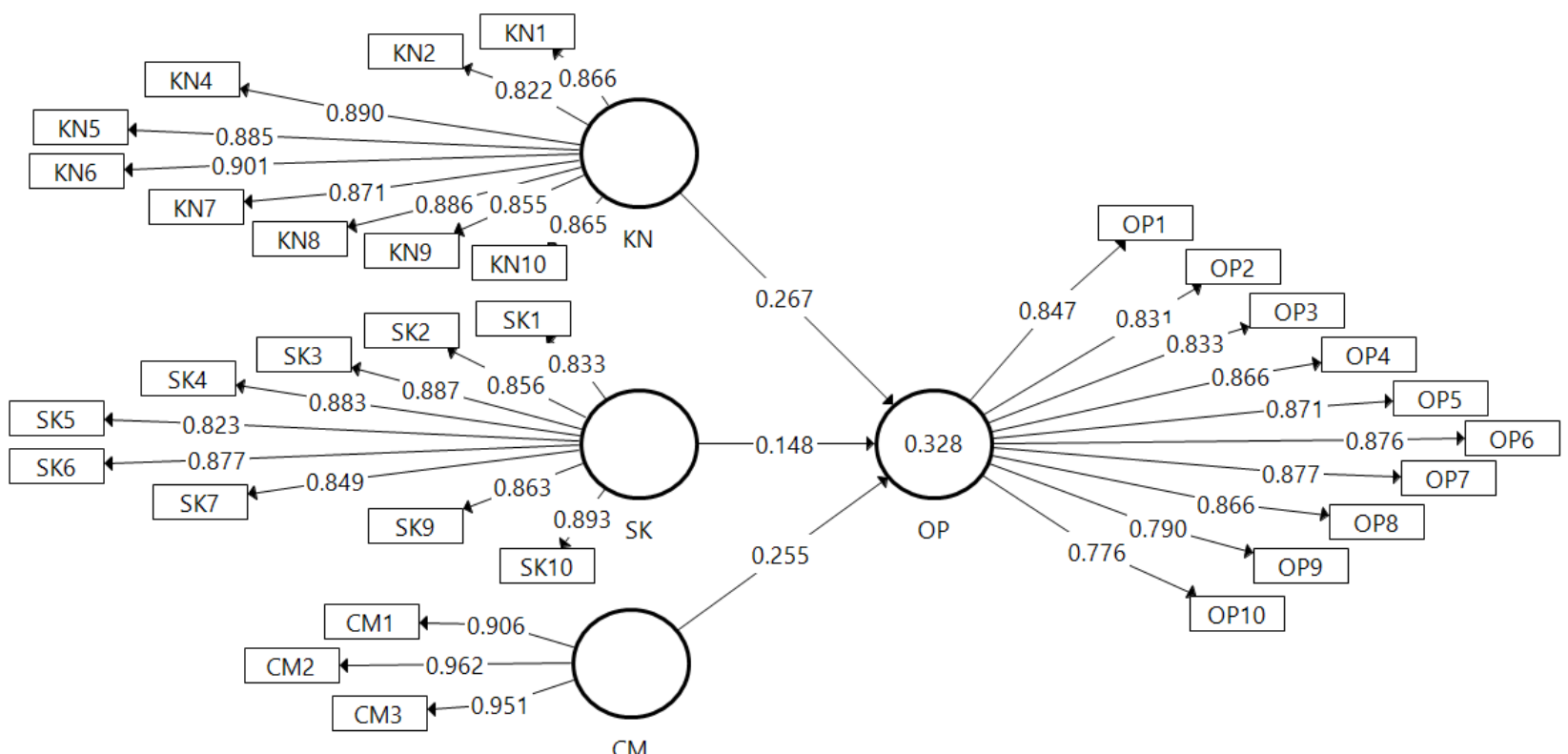

Key:KN: Knowledge, SK: Skills, CM: Competency, OP: Organizational Performance

Fig 2: PLS algorithm results

Figure 2 and Table 4 depict the structural model assessment, showing the results of the hypothesis tests, with 3 out of the 3 hypotheses are supported. Knowledge, skills, and competency significantly predict organizational performance. Hence, $\mathrm{H} 1, \mathrm{H} 2$, and $\mathrm{H} 3$ are accepted with $(\beta=0.267, \mathrm{t}=4.187, \mathrm{p} \quad<0.001)$, $(\beta=0.148, \mathrm{t}=2.088, \mathrm{p} \quad<0.05), \quad$ and $(\beta=0.255, \mathrm{t}=4.461, \mathrm{p}<0.001)$ respectively.

The strength of the relationship between exogenous and endogenous constructs are measured by the standardized path coefficients, which in this case show that the direct effects of Knowledge on organizational performance is much stronger than the influence of other variables.

Thirty-three percent of the variance in organizational performance is explained by knowledge, skills, and competency. The values of $\mathrm{R}^{2}$ have an acceptable level of explanatory power, indicating a substantial model [36].

Table 4: Structural assessment results

\begin{tabular}{clllllcc}
\hline \hline Hypothesis & \multicolumn{1}{c}{ Relationship } & Std Beta & Std Error & t-value & p-value & Decision & $\mathrm{R}^{2}$ \\
\hline $\mathrm{H} 1$ & $\mathrm{KN} \rightarrow \mathrm{OP}$ & 0.267 & 0.064 & 4.187 & 0.000 & Supported \\
$\mathrm{H} 2$ & $\mathrm{SK} \rightarrow$ OP & 0.148 & 0.071 & 2.088 & 0.019 & Supported \\
$\mathrm{H} 3$ & $\mathrm{CM} \rightarrow$ OP & 0.255 & 0.057 & 4.461 & 0.000 & Supported \\
\hline \hline
\end{tabular}

Key: KN: Knowledge, SK: Skills, CM: Competency, OP: Organizational Performance

\section{DISCUSSION}

The main objective of the current study is to address the impact of human capital on organizational performance within public sector UAE. Based on the proposed model, this study improves the understanding of the role played by human capital in terms of skills, knowledge and competency in public sector organizations. The discussions are further detailed in the following.

The study found that knowledgepositively affect organizational performance among organizations in public sector in UAE, this is supported by previous studies [8, 38]. It is explained by the fact that the more the employee can learn what is necessary for a new task, refer to best practices and apply them, use the Internet to obtain knowledge, share the information and knowledge, improves task efficiency by sharing information and knowledge, search information for tasks from various knowledge sources, understand computer programs needed to perform the tasks, and accept new knowledge and apply it. The more the organization can be industry leader, forward-looking organization, responsive to local and international market needs, experience growth in revenue, market share and profit, improve operating efficiency, achieve and sustain superior performance, achieves a high success rate in new service launched, and continuously produce competitive services.

Further the study also found that skills positively affects organizational performance among organizations in public sector in UAE, this is supported by previous studies [9, 39]. It is explained by the fact that the more the employee understands and contributes to the organizational goals, knows the process of making a decision, knows how to weigh the relative importance among different issues, able to change decisions based upon new information, respects the thoughts and opinions of others in the team, treats others with courtesy, accepts individual differences among members, and contributes solutions to resolve problems, the more the organization can be industry leader, forward-looking organization, responsive to local and international market needs, experience growth in revenue, market share and profit, improve operating efficiency, achieve and sustain

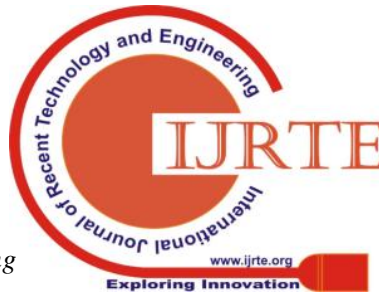


superior performance, achieves a high success rate in new service launched, and continuously produce competitive services.

Lastly, the study also found that competency positively affects organizational performance among organizations in public sector in UAE, this is supported by previous studies [7, Samad, 2012). It is explained by the fact that the more the employee compete to perform his/her job, become effective in doing the job, and actually is qualified to do the job well, the more the organization can be industry leader, forward-looking organization, responsive to local and international market needs, experience growth in revenue, market share and profit, improve operating efficiency, achieve and sustain superior performance, achieves a high success rate in new service launched, and continuously produce competitive services.

\section{IMPLICATIONS, LIMITATIONS AND FUTURE DIRECTIONS}

Employees are the most valuable asset in any organization. Thus, it is crucial for organizations to have capable managers to encourage and inspire their workforce in their daily tasks and fulfill the organizational goals. Previous research have examined those relationships of human capital to gather information about the knowledge, skills, and competency. To further contribute to this area, this research can be seen as an extension of the previous work on human capital as it enriches the theory by adding to the factors of human capital another actor named competency. Moreover, it has examined such interactions in a knowledge-based context which was the public sector. The research outcome revealed these positive cooperative interactions, these prescribed variables have explained $32.8 \%$ of organizational performance variety.

Public sector organizations in UAE should maintain and promote knowledge gaining among its employees to support

\section{APPENDIX}

Appendix A

Instrument for varibles innovation to enhance the performance of the organizations. Subsequently, in public organizationsthe suitable person must be in place, to execute the job and provide employees with the necessary training to enhance their performance and capabilities.

As for limitation, since this study was conductedin organizations in the UAE public sector, the findings may not be generalized to all UAE private sector. With regard to future directions, Future research may merge both qualitative and quantitative methods in measuring organizationalperformance. Besides, it can use interviews and/or case studies to gatherin-depth qualitative data, which would be valuable to learn the possible trends of research.

\section{CONCLUSION}

The purpose of this article was to examine the impact of human capital on the organizational performance in public sector organizations in the UAE. It has provided evidence from leading scholars in the field on the notion of 'human capital' and how investment in education and training is essential to build the employees knowledge and skills required for development of the building blocks of any organization (individuals) and consequently in organizations performance. Moreover, competency of the individuals in any organization is important as it is driver for using and utilizing their knowledge and skills for the good of the organization. Knowledge, skills, and competency were found to influence the performance of the organization. The independent variables significantly explain $32.8 \%$ of organizational performance. The implications of this study have been deliberated, some directions for future research have been suggested.

\begin{tabular}{ll}
\hline Varible & Measure \\
& KN1: The employee can learn what is necessary for a new task \\
KN2: The employee can refer to best practices and apply them to the task. \\
KN3: The employee can use the Internet to obtain knowledge for the task. \\
KN4: The employee shares the information and knowledge necessary for the task. \\
KN5: The employee improves task efficiency by sharing information and knowledge. \\
KN6: The employee fully understands the core knowledge necessary for his tasks. \\
KN7: The employee obtains useful information and suggestions from brainstorming meetings without spending \\
too much time. \\
KN8: The employee search information for tasks from various knowledge sources administered by the \\
organization. \\
KN9: The employee understands computer programs needed to perform the tasks and use them well. \\
KN10: The employee is ready to accept new knowledge and apply it to his tasks when necessary.
\end{tabular}


SK1: The employee understands and contribute to the organizational goals.

SK2: The employee knows the process of making a decision.

SK3: The employee knows how to weigh the relative importance among different issues.

SK4: The employee solicits input for decision making from his team members.

Skills SK5: The employee is able to change decisions based upon new information.

(SK) SK6: The employee respects the thoughts and opinions of others in the team.

SK7: The employee treats others with courtesy.

SK8: The employee accepts individual differences among members.

SK9: The employee can identify potential problems readily.

SK10: The employee willingly contributes solutions to resolve problems.

Competency CM1: The employee is competing in perform his job.

(CM) CM2: The employee is effective in doing his work.

CM3: The employee is qualified to do the job well.

OP1: Our organization industry leader.

OP2: Our organization is a forward-looking organization.

OP3: Our organization is quickly responsive to local and international market needs.

OP4: Our revenue growth is improving.

Organizational OP5: Our market share is improving.

Performance OP6: Our profit growth is improving.

(OP) OP7: Our organization is improving operating efficiency.

OP8: Our organization is always able to achieve and sustain superior performance.

OP9: Our organization practices 'On Time Delivery' of its services to the customers.

OP10: Our organization achieves a high success rate in new service launched.

OP11: Our organization is continuously produce competitive services.

\section{REFERENCES}

1. 1. S. Comu, H. I. Unsal \& J. E. Taylor, (2011). Dual Impact of Cultural and Linguistic Diversity on Project Network Performance. Journal of Management in Engineering, 27(3), pp. 179-187.

2. 2. K. Niebecker, D. Eager \& K. Kubitza (2008). Improving cross-company project management performance with a collaborative project scorecard. International Journal of Managing Projects in Business, 1(3), pp. 368-386.

3. 3. Z. Nedelko \& V. Potočan, (2013). The role of management innovativeness in modern organizations. Journal of Enterprising Communities: People and Places in the Global Economy, 7(1), pp. 36-49.

4. 4. J. A. Aragón-Correa, V. J. García-Morales \& E. Cordón-Pozo, (2007). Leadership and organizational learning's role on innovation and performance: Lessons from Spain. Industrial Marketing Management, 36(3), 349-359.

5. 5. M. J. Donate \& J. D. Sánchez de Pablo, (2015). The role of knowledge-oriented leadership in knowledge management practices and innovation. Journal of Business Research, 68(2), pp. 360-370.

6. 6. C. Andriopoulos \& M. W. Lewis, (2010). Managing Innovation Paradoxes: Ambidexterity Lessons from Leading Product Design Companies. Long Range Planning, 43(1), pp. 104-122.

7. 7. M. Afacan Findiklı, U. Yozgat \& Y. Rofcanin (2015). Examining Organizational Innovation and Knowledge Management Capacity the Central Role of Strategic Human Resources Practices (SHRPs). Procedia - Social and Behavioral Sciences, 181, pp. 377-387.

8. 8. M. Heffernan, B. Harney, K. Cafferkey, \& T. Dundon, (2016). Exploring the HRM-performance relationship: the role of creativity climate and strategy. Employee Relations, 38(3), pp. 438-462.

9. 9. C. Gavrea, L. Ilies \& R. Stegerean, (2011). Determinants of organizational performance: The case of Romania. Management \& Marketing, 6(2), pp. 285-300.

10. 10. P. J. Richard, T. M. Devinney, G. S. Yip \& G. Johnson, (2009). Measuring Organizational Performance: Towards Methodological Best Practice. Journal of Management, 35(3), pp. 718-804.

11. 11. J. B. Barney, (1991). Firm Resources and Sustained Competitive Advantage. Journal of Management.

12. 12. OECD. (2004). OECD Principles of Corporate Governance 2004. France: OECD Publications.

13. 13. G.S. Becker (1993). Human Capital: A Theoretical and Empirical Analysis, with Special Reference to Education.

14. 14. T. W. Schultz, (1971). Investment in Human Capital: The Role of Education and of Research. Free Press.

15. 15. W. H. A. Johnson, (1999). An integrative taxonomy of intellectual capital: measuring the stock and flow of intellectual capital components in the firm. International Journal of Technology Management, 18(5-8), pp. 562-575.
16. 16. M. A. Youndt, M. Subramaniam \& S. A. Snell, (2004). Intellectual Capital Profiles: An Examination of Investments and Returns*. Journal of Management Studies, 41(2), pp. 335-361.

17. 17. W. Wang \& C. Chang, (2005). Intellectual capital and performance in causal models: Evidence from the information technology industry in Taiwan. Journal of Intellectual Capital, 6(2), pp. 222-236.

18. 18. J. Yang (2004). Job-related knowledge sharing: comparative case studies. Journal of Knowledge Management, 8(3), pp. 118-126.

19. 19. P. F. Drucker, (1977). People and performance: the best of Peter Drucker on management. HarperCollins Canada, Limited.

20. 20. A. Toffler (1990). Powershift: knowledge, wealth, and violence at the edge of the 21 st century. Bantam Books.

21. 21. I. Nonaka \& H. Takeuchi, (1995). The Knowledge-creating Company: How Japanese Companies Create the Dynamics of Innovation. Oxford University Press.

22. 22. R. Winter, (1987). Action-Research and the Nature of Social Inquiry: Professional Innovation and Educational Work. Avebury.

23. 23. I. Nonaka, G. von Krogh \& S. Voelpel, (2006). Organizational Knowledge Creation Theory: Evolutionary Paths and Future Advances. Organization Studies, 27(8), pp. 1179-1208.

24. 24. M. Hamori, R. Bonet \& P. Cappilli, (2011). How organizations obtain the human capital they need. In The Oxford handbook of human capital (pp. 309-322).

25. 25. S. Snell \& J. W. J. Dean, (1992). Integrated Manufacturing and Human Resource Management: A Human Capital Perspective. Academy of Management Journal, 35.

26. 26. M. Gaber \& A. Fahim, (2018). Strategic human resource management and public employee retention. Review of Economics and Political Science, 3(2), pp. 20-39.

27. 27. B. C. Lee, J. O. Yoon \& I. Lee, (2009). Learners' acceptance of e-learning in South Korea: Theories and results. Computers and Education, 53(4), pp. 1320-1329.

28. 28. O. Isaac, Z. Abdullah, T. Ramayah, \& A. M. Mutahar, (2017a). Examining the Relationship Between Overall Quality, User Satisfaction and Internet Usage: An Integrated Individual, Technological, Organizaional and Social Perspective. Asian Journal of Information Technology, 16(1), pp. 100-124.

29. 29. B. G. Tabachnick \& L. S. Fidell, (2012). Using Multivariate Statistics (6th ed.). New York: Pearson.

30. 30. R. V. Krejcie \& D. W. Morgan, (1970). Determining Sample Size for Research Activities Robert. Educational and Psychological Measurement, 38(1), pp. 607-610.

31. 31. J. C. Anderson \& D. W. Gerbing, (1988). Structural equation modeling in practice: A review and recommended two-step approach. Psychological Bulletin, 103(3), pp. 411-423. 
32. 32. V. R. Kannana \& K. C. Tan, (2005). Just in time, total quality management, and supply chain management: understanding their linkages and impact on business performance. Omega: The International Journal of Management Science, 33(2), pp. 153-162.

33. 33. C. E. Werts, R. L. Linn \& K. G. Jöreskog, (1974). Intraclass reliability estimates: Testing structural assumptions. Educational and Psychological Measurement, 34(1), pp. 25-33.

34. 34. R. B. Kline, (2010). Principles and practice of structural equation modeling (3rd ed.). New York: The Guilford Press.

35. 35. C. Fornell \& D. F. Larcker, (1981). Evaluating structural equation models with unobservable variables and measurement error. Journal of Marketing Research, 18(1), pp. 39-50.

36. 36. W. W. Chin (1998a). Issues and opinion on structural equation modeling. MIS Quarterly, 22(1), pp. 7-16.

37. 37. J. F. Hair, G. T. M. Hult, C. Ringle \& M. Sarstedt, (2017). A Primer on Partial Least Squares Structural Equation Modeling (PLS-SEM) (2nd ed.). London: Thousand Oaks: SAGE.

38. 38. V. J. García-Morales, M. M. Jiménez-Barrionuevo, \& L. Gutiérrez-Gutiérrez, (2012). Transformational leadership influence on organizational performance through organizational learning and innovation. Journal of Business Research, 65(7), pp. 1040-1050.

39. 39. S. Aydogdu \& B. Asikgil, (2011). The Effect of Transformational Leadership Behavior on Organizational Culture: An Application in Pharmaceutical Industry. International Review of Management and Marketing, 1(4), pp. 65-73.

40. 40. K. C. Lee, S. Lee \& I. W. Kang (2005). KMPI: measuring knowledge management performance. Information \& Management, 42(3), pp. 469-482.

41. 41. C. J. Brungardt, (2009). College graduates' perceptions of their use of teamwork skills: Soft skill development in Fort Hays State University leadership education. KANSAS STATE UNIVERSITY, Manhattan, Kansas.

42. 42. M. Pinar \& T. Girard, (2008). Investigating the Impact of Organizational Excellence and Leadership on Achieving Business Performance: An Exploratory Study of Turkish Firms. Advanced Management Journal, 73(1), pp. 29-45.

\section{AUTHORS PROFILE}

Mohamad Alhamad Faculty of Business and Accountancy, Lincoln University College, Selangor, Malaysia

Mohammed Nusari Faculty of Business and Accountancy, Lincoln University College, Selangor, Malaysia

Ali Ameen Faculty of Business and Accountancy, Lincoln University College, Selangor, Malaysia

Valliappan Raju Faculty of Business and Accountancy, Lincoln University College, Selangor, Malaysia

Amiya Bhumic Faculty of Business and Accountancy, Lincoln University College, Selangor, Malaysia 